\title{
Midges of the genus Pseudodiamesa Goetghebuer (Diptera, Chironomidae): current knowledge and palaeoecological perspective
}

\author{
Boris P. Ilyashuk • Elena A. Ilyashuk • \\ Eugeny A. Makarchenko - Oliver Heiri
}

Received: 20 September 2009/Accepted: 22 May 2010/Published online: 8 June 2010

(C) The Author(s) 2010. This article is published with open access at Springerlink.com

\begin{abstract}
Larvae of the genus Pseudodiamesa Goetghebuer, which includes 12 described valid species and is divided by Makarchenko and Makarchenko (1999) into two species groups, Pseudodiamesa branickii group and Pseudodiamesa nivosa group, are widespread in lakes and running waters of cold, high-latitude and high-altitude areas of the Northern Hemisphere. Larval remains of the genus are often found in subfossil assemblages from these
\end{abstract}

B. P. Ilyashuk $(\bowtie) \cdot$ O. Heiri

Institute of Environmental Biology, Palaeoecology, Laboratory of Palaeobotany and Palynology, Utrecht University, Budapestlaan 4, 3584 CD Utrecht, The Netherlands

e-mail: ilboris@yandex.ru

\section{E. A. Ilyashuk}

Institute of Ecology, University of Innsbruck,

Technikerstraße 25, 6020 Innsbruck, Austria

B. P. Ilyashuk · E. A. Ilyashuk

Institute of North Industrial Ecology Problems, Kola

Science Centre, Russian Academy of Sciences, 14

Fersman St., Apatity, Murmansk reg. 184209, Russia

\section{E. A. Makarchenko}

Institute of Biology and Soil Sciences, Russian Academy of Sciences, Far East Branch, 100 let Vladivostoku Ave. 159, Vladivostok 690022, Russia

\section{O. Heiri}

Institute of Plant Sciences and Oeschger Centre for Climate Change Research, University of Bern,

Altenbergrain 21, 3013 Bern, Switzerland cold regions, but intra-genus morphotypes usually are not distinguished by palaeoecologists. Current knowledge of the ecology of the species indicates that the Pseudodiamesa nivosa group is more cold-adapted than the Pseudodiamesa branickii group and, therefore, these two intra-genus morphotypes cannot be amalgamated into a larger taxonomic unit without losing substantial information. Here we present the morphological characters of head capsules of Pseudodiamesa larvae attributed to the different speciesgroup morphotypes, which are clearly visible in subfossil specimens. The information summarized in this paper will help provide more reliable chironomid-based palaeoclimatic inferences from lake sediment records covering colder phases through the late Quaternary in the Northern Hemisphere.

Keywords Chironomids - Pseudodiamesa . Larval subfossils $\cdot$ Taxonomy $\cdot$ Palaeoclimate

\section{Introduction}

Species of the genus Pseudodiamesa Goetghebuer, 1939 are relatively large chironomids (non-biting midges), which are recorded from all continents of the Northern Hemisphere (Pagast 1947). The taxonomy of this genus from the subfamily Diamesinae is based mainly on morphological characters of the adult males (Makarchenko 1985; Oliver 1989), but the larvae of the different Pseudodiamesa species are 
morphologically similar and can be difficult to separate (Oliver 1983; Makarchenko and Makarchenko 1999; Makarchenko 2006). This genus was divided into two subgenera, Pachydiamesa Oliver, 1959 and Pseudodiamesa s. str. by Oliver (1959). The first subgenus is represented by only one Nearctic species, Pseudodiamesa arctica (Malloch), and the second subgenus includes all other known species of this genus, following the nomenclature of Oliver (1959, 1983). Makarchenko and Makarchenko (1999) suggested applying a species-group nomenclature to the Pseudodiamesa larvae and dividing the genus into two species groups, the Pseudodiamesa branickii group and the Pseudodiamesa nivosa group. According to the nomenclature of Makarchenko and Makarchenko (1999), the first species group is represented by two species, namely Pseudodiamesa branickii (Nowicki) and Pseudodiamesa pertinax (Garret), and the Pseudodiamesa nivosa group includes all other known species (Table 1). Hereafter, we use the species-group nomenclature to differentiate Pseudodiamesa larvae within the genus, as this nomenclature is based on different morphological characters of the larval head capsules and can be applied to chironomid subfossil material represented by larval remains.

The genus Pseudodiamesa is known as one of the cold-adapted chironomid taxa (Serra-Tosio 1976; Barley et al. 2006; Heiri and Lotter 2008). Larvae of both species groups are widespread in lakes and running waters of cold areas of the Holarctic and Oriental regions (Pagast 1947; Manca et al. 1998; Oliver et al. 1990; Makarchenko and Makarchenko 1999). Studies of fossil chironomid assemblages indicate that Pseudodiamesa was common in lakes during past cold climate phases of the late Quaternary (Ilyashuk et al. 2008; Kurek et al. 2009).

High-latitude and high-altitude regions are especially sensitive to the effects of recent climate warming (Ørbæk et al. 2004). In recent years, palaeoclimate studies in these remote regions have received increasing attention by the scientific community. Interest in chironomid-based palaeoclimate inferences has grown, especially over the past decade, driven largely by the potential for using chironomids to infer palaeotemperatures accurately and independently of other methods (Walker and Cwynar 2006). Larval remains of the genus Pseudodiamesa are quite often found in subfossil chironomid assemblages from these cold regions, but intra-genus morphotypes are usually not distinguished by palaeoecologists (Larocque et al. 2001; Barley et al. 2006; Heiri and Lotter 2008). Previous studies in the European Alps (Pagast 1947; Serra-Tosio 1973, 1976; Rossaro et al. 2006) and the Nepalese Himalayas (Manca et al. 1998), however, have shown that the Pseudodiamesa species, which can be attributed to different species groups, but live together in these mountain areas, prefer different altitudes and/or temperature conditions within lakes and streams. As demonstrated by Brooks et al. (2007), many morphotypes within other genera show different distributions along environmental gradients than the genus as a whole, and therefore have the potential to be useful palaeoecological indicators. Thus, identification of Pseudodiamesa subfossil remains to a more precise taxonomic level would provide more reliable palaeoclimate inferences.

The aim of this work was to assess whether intragenus morphotypes of Pseudodiamesa larvae can be differentiated reliably in subfossil material from surface and down-core samples. To achieve this objective, it is necessary to determine the morphological characters of head capsules of Pseudodiamesa larvae that are clearly visible in subfossil remains. Here we used subfossil specimens represented by both Pseudodiamesa species groups, which were collected in the European Alps and Northern Russia to examine several key morphological features described in the available literature for identification of contemporary Pseudodiamesa larvae. In addition, we provide a short summary of the zoogeography and ecology of Pseudodiamesa species, which will contribute to palaeoecological interpretation of subfossil records.

\section{Zoogeography}

At the end of the twentieth century, there were 11 valid Pseudodiamesa species known to science from the Holarctic and Oriental regions (Makarchenko and Makarchenko 1999). More recently, a twelfth species, Pseudodiamesa sunabacedea Tanaka and Sasa, was described from Japan (Tanaka and Sasa 2001) (Table 1).

At present, three Pseudodiamesa species are known from the Nearctic, where they are recorded only from western and northern areas (Oliver et al. 1990; Epler 2001). The P. nivosa group is represented 
Table 1 Distribution of Pseudodiamesa species in the zoogeographic regions: (+) presence and (-) absence

\begin{tabular}{|c|c|c|c|c|c|c|c|c|}
\hline \multirow[t]{2}{*}{ Region } & \multirow[t]{2}{*}{ Nearctic $^{\mathrm{a}}$} & \multicolumn{3}{|c|}{ Western Palaearctic } & \multicolumn{3}{|c|}{ Eastern Palaearctic } & \multirow[t]{2}{*}{ Oriental $^{\mathrm{b}}$} \\
\hline & & $\begin{array}{l}\text { Northern } \\
\text { Africa }\end{array}$ & $\begin{array}{l}\text { Western } \\
\text { Europe }\end{array}$ & $\begin{array}{l}\text { Eastern } \\
\text { Europe }\end{array}$ & $\begin{array}{l}\text { Northern } \\
\text { Asia }\end{array}$ & $\begin{array}{l}\text { Central } \\
\text { Asia }\end{array}$ & Japan & \\
\hline \multicolumn{9}{|l|}{ Pseudodiamesa branickii group } \\
\hline P. branickii (Nowicki 1873) & + & + & + & + & + & + & + & + \\
\hline P. pertinax (Garret 1925) & + & - & - & - & - & - & - & - \\
\hline \multicolumn{9}{|l|}{ Pseudodiamesa nivosa group } \\
\hline P. arctica (Malloch 1919) & + & - & - & - & - & - & - & - \\
\hline P. nivosa (Goetghebuer 1928) & - & + & + & + & + & + & - & - \\
\hline P. stackelbergi (Goetghebuer 1933) & - & - & - & + & + & - & + & - \\
\hline P. nepalensis Reiss, 1968 & - & - & - & - & - & - & - & + \\
\hline P. gorodkovi Makarchenko, 1983* & - & - & - & + & - & - & - & - \\
\hline P. venusta Makarchenko, 1984 & - & - & - & - & - & + & - & - \\
\hline P. latistyla Makarchenko, 1989 & - & - & - & - & + & - & - & - \\
\hline P. vetusta Makarchenko, 1989* & - & - & - & - & - & + & - & - \\
\hline P. mongolzecea Sasa and Suzuki, 1997* & - & - & - & - & - & + & - & - \\
\hline P. sunabacedea Tanaka and Sasa, 2001* & - & - & - & - & - & - & + & - \\
\hline References & 1,2 & 3,4 & 5,6 & $7-9$ & $8,10-12$ & 11,13 & 14,15 & 16,17 \\
\hline
\end{tabular}

References: 1 Oliver et al. (1990), 2 Epler (2001), 3 Pagast (1947), 4 Kettani et al. (2001), 5 Sæther and Spies (2004), 6 Makarchenko (2009), 7 Goetghebuer (1933), 8 Pankratova (1970), 9 Makarchenko (1983), 10 Linevich (1989), 11 Makarchenko (1989), 12 Makarchenko (2006), 13 Hayford (2005), 14 Makarchenko (1993), 15 Tanaka and Sasa (2001), 16 Roback and Coffman (1987), 17 Manca et al. (1998)

* Immature stages are unknown

${ }^{\text {a }}$ Are recorded only from western and northern areas

b Only from the Nepalese Himalayas

there by $P$. arctica, and the $P$. branickii group is represented by two species, $P$. branickii and $P$. pertinax.

In the Palaearctic and Oriental regions, the P. branickii group is represented only by widespread $P$. branickii. The $P$. nivosa group is represented by one species, Pseudodiamesa nepalensis Reiss, in the Oriental region (Nepalese Himalayas; Manca et al. 1998) and by eight other species in the Palaearctic region. Among the Palaearctic Pseudodiamesa species belonging to the $P$. nivosa group, Pseudodiamesa nivosa (Goetghebuer) is the most widely distributed species known from both eastern and western areas of the Palaearctic (Table 1). Schnell and Willassen (1991) suggested that the Nearctic P. arctica and the Palaearctic $P$. nivosa are the same species and should be named $P$. arctica, as this is the older name (Sæther and Spies 2004). Makarchenko (2009), however, compared adult morphological characteristics of both species and showed that they are two valid sister species.

Another of the widely distributed Palaearctic species from the P. nivosa group is Pseudodiamesa stackelbergi (Goetghebuer) known from both eastern and western areas. The other species are restricted to smaller areas of the Palaearctic. Furthermore, the immature stages of the four Palaearctic species are unknown (Table 1).

\section{Ecology}

Larvae of the genus Pseudodiamesa are detritus feeders that gather fine particulate organic matter, but can prey on smaller chironomids and other small aquatic invertebrates as well (Pagast 1947). The species are well adapted to harsh physical environments and can complete their life cycle where water temperatures never exceed $2^{\circ} \mathrm{C}$ (Milner et al. 2001). 
On the other hand, the larvae can enter diapause during relatively long periods of low temperatures, when conditions are not suitable for activity. Usually, all instars develop during summer, enter diapause at the 4th instar, and emerge synchronously the next year during the springtime thaw period (Oliver 1959; Tátosová and Stuchlík 2006). Adults of Pseudodiamesa emerge through cracks in the ice cover at the onset of thawing, and can copulate on the snow cover at sub-zero temperatures $\left(-1\right.$ to $-2^{\circ} \mathrm{C}$; Oliver 1964 ; Danks and Oliver 1972; Hågvar and Østbye 1973). Diapausal eggs of Pseudodiamesa, frozen and covered by snow, were also found in early spring near an Alpine glacial stream (Lencioni 2004). In contrast to the high degree of synchrony observed in mountain and Arctic lakes, stream studies suggest that emergence is not synchronized by diapause (Hayes and Murray 1987). Studies from North America and Europe indicated that the Pseudodiamesa species are usually univoltine (Oliver 1959; Tátosová and Stuchlík 2006). However, there is evidence that $P$. branickii exhibits bi- and trivoltinism under warmer conditions at lower altitudes and latitudes (Nolte and Hoffmann 1992).

Our knowledge of the ecology of the Pseudodiamesa species is still fragmentary. The most comprehensive studies of the ecology and distribution of the Pseudodiamesa species are from Western Europe, where the genus is represented by $P$. branickii and $P$. nivosa, i.e. every species group is represented by a single species. Both species are common and widespread taxa in the European Alps (Boggero et al. 2006; Rossaro et al. 2006), the Tatra Mountains (Bitušík et al. 2006; Krno et al. 2006), the Pyrenees (Rieradevall and Prat 1999), Arctic and sub-arctic regions of Fennoscandia (Paasivirta 2009) and Iceland (Langdon et al. 2008). In the European Alps, $P$. branickii prefers altitudes between 200 and 2,300 $\mathrm{m}$ asl, whereas $P$. nivosa dwells mainly at altitudes of 2,000-3,000 m asl (Pagast 1947; SerraTosio 1973; Janecek 1998). Nevertheless P. nivosa can also colonize cold habitats of the periglacial zones at lower altitudes, 345-230 m asl (Siciński 1988).

Though both Pseudodiamesa species are known from lakes and running waters of Western Europe, P. nivosa prefers the cold profundal of Arctic and alpine lakes, where in some cases it displays very abundant populations (Nauwerck 1981; Lindegaard
1992; Tátosová and Stuchlík 2006). P. branickii is more common in running waters and the littoral zone of lakes (Bretschko 1974; Boggero et al. 2006; Rossaro et al. 2006). Previous studies of chironomids from European glacier-fed streams have shown that $P$. nivosa survives in the first $100 \mathrm{~m}$ from a glacier, where water temperature does not exceed $2^{\circ} \mathrm{C}$. It colonises downstream habitats with maximum temperature $<9^{\circ} \mathrm{C}$, whereas $P$. branickii is associated with "non-glacial" conditions and can be very abundant further downstream in biotopes where the water temperature does not exceed $18^{\circ} \mathrm{C}$ (Janecek et al. 2002; Lods-Crozet et al. 2001; Lencioni and Rossaro 2005). According to Rossaro et al. (2006), who calculated water temperature optima for the chironomid taxa living in running waters in the Southern European Alps above 800-1,000 m asl, $P$. branickii is characterised by a higher temperature optimum than $P$. nivosa $\left(4.90\right.$ and $4.45^{\circ} \mathrm{C}$, respectively). In addition, the larvae of both species tolerate low $\mathrm{pH}$ and occur in acidified lakes and streams (Braukmann and Biss 2004; Bitušík et al. 2006).

The Pseudodiamesa species from Nearctic and Oriental regions demonstrate a similar difference in ecological preferences of the two species-group morphotypes. The Nearctic $P$. arctica and the Oriental $P$. nepalensis, both belonging to the $P$. nivosa group, prefer the cold profundal of lakes and, like their sister species $P$. nivosa in the Palaearctic region, often produce very abundant populations in large arctic lakes of North America (Oliver 1964, 1976) and in deep, high alpine lakes and glacial pools of the Nepalese Himalayas (Roback and Coffman 1987; Manca et al. 1998), respectively. Both species belonging to the $P$. branickii group from North America, P. pertinax and P. branickii, occupy similar warmer biotopes, namely the littoral zone of lakes and "non-glacial" habitats of springs and streams (Mackay 1969; Elgmork and Sæther 1970; Sæther 1970). Mackay (1969) found that the Nearctic $P$. pertinax is able to survive in the stream biotopes where the water temperature reaches $17.2^{\circ} \mathrm{C}$. In high alpine lakes of the Oriental region, P. branickii is also restricted to habitats within the warmer littoral (Manca et al. 1998).

The information presented above suggests that the $P$. nivosa group is more cold-adapted than the $P$. branickii group, which occurs under more moderate conditions. Unfortunately, our knowledge of the 
ecology of some Eastern Palaearctic species belonging to the $P$. nivosa group is poor. The distribution and ecology of the four species is restricted and comes only from the occurrence of the adult forms. It would be helpful to study the adults and immatures together, but this is not always practical. Current knowledge of the ecology of both species groups suggests that all the sister species forming the $P$. nivosa group have similar environmental preferences within different zoogeographic regions.

\section{Materials and methods}

Subfossil material from surface and down-core samples gathered in the European Alps and Northern Russia was used in this study. Material including Pseudodiamesa nivosa species-group subfossils was taken from sediment sequences (core tops and lower parts) retrieved from three sites: (1) Nikolay Lake, a large Arctic lake situated in northeast Russia $\left(73^{\circ} 20^{\prime} \mathrm{N}, 124^{\circ} 12^{\prime} \mathrm{E}\right.$; $\sim 1 \mathrm{~m}$ asl); (2) Schwarzsee ob Sölden, a high alpine lake located at 2,796 $\mathrm{m}$ asl in the Ötztaler Alps, Austria $\left(46^{\circ} 58^{\prime} \mathrm{N}, 10^{\circ} 57^{\prime} \mathrm{E}\right)$; and a palaeo-lake near the Maloja Pass, Central Alps, Switzerland $\left(46^{\circ} 24^{\prime} \mathrm{N}, 9^{\circ} 41^{\prime} \mathrm{E} ; 1,865 \mathrm{~m}\right.$ asl). Cores were collected at all three sites to produce late Quaternary palaeoclimate reconstructions (Andreev et al. 2004; Ilyashuk et al. 2008, 2009). Material including Pseudodiamesa branickii species-group subfossils was taken from surface and down-core sediment samples that were collected from Lake Golcovoe, a subarctic lake situated on the Kola Peninsula, northwest Russia $\left(67^{\circ} 50^{\prime} \mathrm{N} \quad 33^{\circ} 40^{\prime} \mathrm{E}\right.$; $208 \mathrm{~m}$ asl), and from surface sediment samples collected at Weißenbach, a first-order tributary of the Inn River, Austria $\left(47^{\circ} 17^{\prime} \mathrm{N}, 11^{\circ} 31^{\prime} \mathrm{E} ; 605 \mathrm{~m}\right.$ asl). In addition, material including subfossils of both the Pseudodiamesa species groups was taken from surface sediment samples collected at Matscherjochsee, a high alpine lake located $3,188 \mathrm{~m}$ asl in the Italian Alps $\left(46^{\circ} 47^{\prime} \mathrm{N}, 10^{\circ} 41^{\prime} \mathrm{E}\right)$. At least 40 Pseudodiamesa head capsules from every site were examined.

The Pseudodiamesa head capsules were picked from the fresh sediment in a Bogorov counting tray at 40-50× magnification under a stereomicroscope. After dehydration they were mounted on glass slides in Euparal $^{\circledR}$ mounting medium for microscopic identification. Taxonomic identification of the
Pseudodiamesa intra-genus morphotypes was accomplished using different key morphological characters of the larval head capsules described in Oliver (1959, 1983), Makarchenko (1985, 2006), Schmid (1993), Janecek (1998), Makarchenko and Makarchenko (1999), and Epler (2001). Morphological terminology is consistent with that of Sæther (1980).

\section{Results}

Key morphological characters: contemporary versus subfossil material

The Pseudodiamesa larvae belonging to the different species groups are separable by several morphological characters, namely by antennal ratio, pecten epipharyngis, mandibular seta interna, and mentum, following Makarchenko and Makarchenko (1999). Morphological features of the larval head capsules described in the identification keys to the contemporary Pseudodiamesa larvae, and summarised in Table 2, were used to identify subfossil specimens.

\section{Labral lamellae and labral setae SI}

The larvae of $P$. arctica can be separated from all other Pseudodiamesa species by having labral lamellae (Oliver 1959, 1983). The larvae of $P$. arctica and $P$. pertinax belonging to the $P$. nivosa group and the $P$. branickii group, respectively, are separable from all other Pseudodiamesa species by the shape of labral setae SI. $P$. arctica has simple seta-like SI and $P$. pertinax has apically bifid SI, whereas all known larvae of other Pseudodiamesa species are characterized by lamelliform SI (Oliver 1983). Unfortunately, labral lamellae and labral setae SI are rarely preserved in subfossil specimens and these characters thus cannot be used to distinguish chironomid taxa in subfossil material.

\section{Mandibular seta interna}

Mandibular setae interna of the $P$. nivosa group consist of 14-24 branches according to Makarchenko (1985, 2006) and Makarchenko and Makarchenko (1999), and 18-23 branches according to Schmid (1993), whereas mandibular setae interna of the P. branickii group consist of 9-15 branches (10-15 
Table 2 Morphological characters of the Pseudodiamesa larval head capsules for identification of the species-group morphotypes within contemporary and subfossil material

\begin{tabular}{|c|c|c|c|c|}
\hline Characters & P. branickii group & $P$. nivosa group & References & $\begin{array}{l}\text { Applicability } \\
\text { to subfossils }\end{array}$ \\
\hline Labral lamellae & Absent & Present* or absent & 1,2 & - \\
\hline Setae SI & Apically bifid** or lamelliform & Simple* or lamelliform & 1,2 , personal observation & + \\
\hline $\begin{array}{l}\text { Mandibular seta } \\
\text { interna }\end{array}$ & With $9-15$ branches & With $14-24$ branches & $3-6$, personal observation & + \\
\hline Antennal ratio & $<2.5$ & $\geq 2.5$ & $\begin{array}{l}\text { 3-7, personal observation } \\
\text { (Fig. 1a, b) }\end{array}$ & ++ \\
\hline $\begin{array}{l}\text { Pecten } \\
\text { epipharyngis }\end{array}$ & $\begin{array}{l}\text { Single median scale and } 3 \text { pairs } \\
\text { of lateral scales }\end{array}$ & $\begin{array}{l}\text { Two median scales and } 2-3 \text { pairs } \\
\text { of lateral scales }\end{array}$ & $\begin{array}{l}3,5,6,8, \text { personal } \\
\text { observation (Fig. 1c-f) }\end{array}$ & ++ \\
\hline Mentum & $\begin{array}{l}\text { Median tooth as dark as lateral } \\
\text { teeth }\end{array}$ & $\begin{array}{l}\text { Median tooth lighter than lateral } \\
\text { teeth }\end{array}$ & $\begin{array}{l}\text { 3, } 5,6 \text {, personal observation } \\
\quad \text { (Fig. } 1 \text { g-j) }\end{array}$ & +++ \\
\hline
\end{tabular}

References: 1 Oliver (1959), 2 Oliver (1983), 3 Makarchenko (1985), 4 Schmid (1993), 5 Makarchenko and Makarchenko (1999), 6 Makarchenko (2006), 7 Janecek (1998), 8 Epler (2001). Applicability within subfossils: non-applicable (-) and applicable within $<5 \%(+), \leq 30 \%(++)$, or $\leq 100 \%(+++)$ of subfossils

* Only P. arctica

** Only P. pertinax

branches according to Schmid (1993) and 9-13 according to Makarchenko $(1985,2006)$ and Makarchenko and Makarchenko (1999)). Unfortunately, the mandibular setae interna are rarely preserved and usually absent in subfossil specimens (Table 2).

\section{Antennal ratio and pecten epipharyngis}

Other key morphological features for the separation of the Pseudodiamesa species-group morphotypes are the antennal ratio and pecten epipharyngis, which are often preserved in subfossil specimens (up to $30 \%$ of subfossils; Table 2) (Fig. 1a-f). The antenna of the $P$. nivosa-group larvae is characterized by an antennal ratio $\geq 2.5$, whereas the antennal ratio of the P. branickii group is <2.5 (Makarchenko 1985, 2006; Schmid 1993; Janecek 1998; Makarchenko and Makarchenko 1999). The pecten epipharyngis of the $P$. nivosa-group larvae consists of an even number, namely 3-4 pairs, of broad, elongate, apically blunt scales (Fig. 1c, d), but that of the $P$. branickii-group larvae is characterized by an odd number, namely seven scales (Fig. 1e, f) (Makarchenko 1985, 2006; Makarchenko and Makarchenko 1999; Epler 2001) (Fig. 1e, f). Our inspection of the subfossils showed that the pecten epipharyngis of the species P. branickii consists of seven very weakly sclerotized scales
(Fig. 1e, f), whereas that of the species $P$. nivosa consists of six strongly sclerotized scales (Fig. 1c, d). The pecten epipharyngis consisting of seven scales was assigned mistakenly to the species $P$. nivosa by Schmid (1993) and Janecek (1998), and to all the Pseudodiamesa species in Oliver (1983), whereas the species $P$. arctica has a pecten epipharyngis consisting of eight scales (E. Makarchenko, personal observation). In both species groups, two outer pairs of scales often overlap the chaetulae laterales and are difficult to see. Median scales, having paired or unpaired character, can however, be used for the separation of the Pseudodiamesa species-groups (Makarchenko and Makarchenko 1999; Makarchenko 2006) (Table 2).

\section{Mentum}

The mentum is a well-preserved structure in subfossil specimens and can be one of the best morphological characters for differentiating Pseudodiamesa speciesgroup morphotypes in subfossil material. All teeth of the mentum of the $P$. branickii-group are similar in colour, whereas the $P$. nivosa group has a mentum with a lighter median tooth than the lateral black teeth (Makarchenko 1985, 2006; Makarchenko and Makarchenko 1999) (Fig. 1g-j). In addition, lateral 
Fig. 1 Pseudodiamesa: antenna (a, b); labroepipharyngeal region and median scales (MS) of pecten epipharyngis (c, e); pecten epipharyngis and median scales (MS) (d, f); unflattened mentum of 3rd (g), 4th (h, i), and 2nd (k) instars; flattened mentum of 4 th instar (j). Pseudodiamesa nivosa (Goetghebuer) (a, c, d, $\mathbf{g}, \mathbf{h}) ;$ Pseudodiamesa branickii (Nowicki) (b, e, f, i, j); Pseudodiamesa ind. (k)

\section{Pseudodiamesa nivosa group}
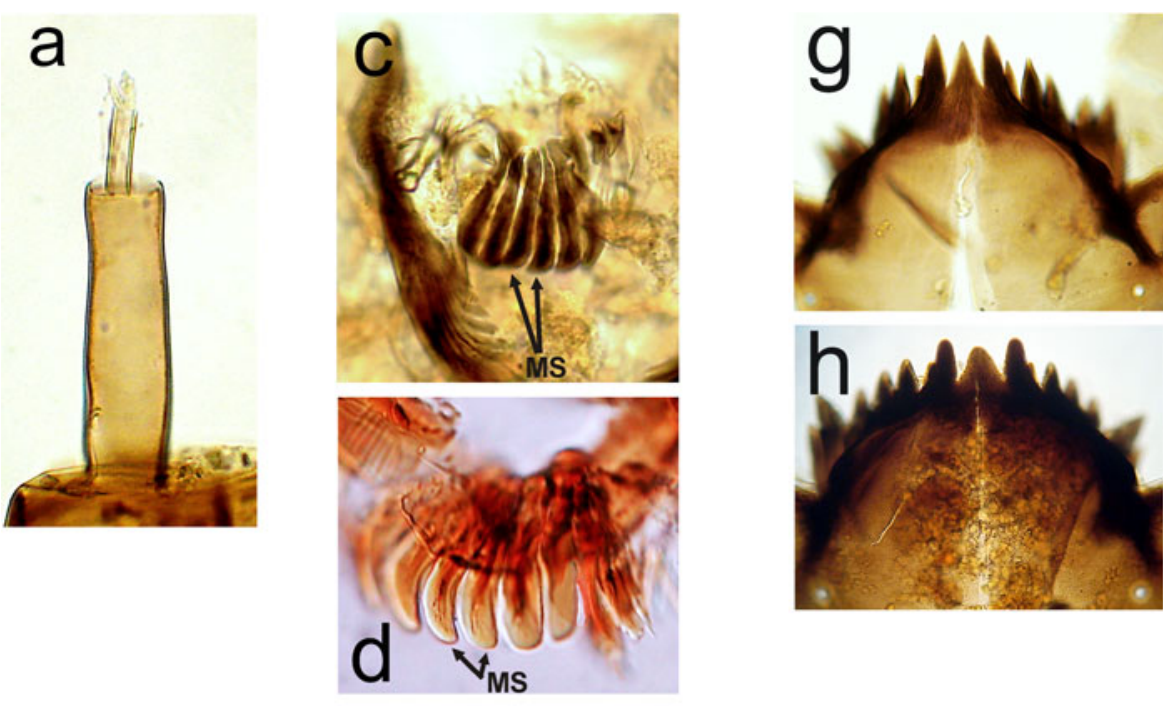

Pseudodiamesa branickii group
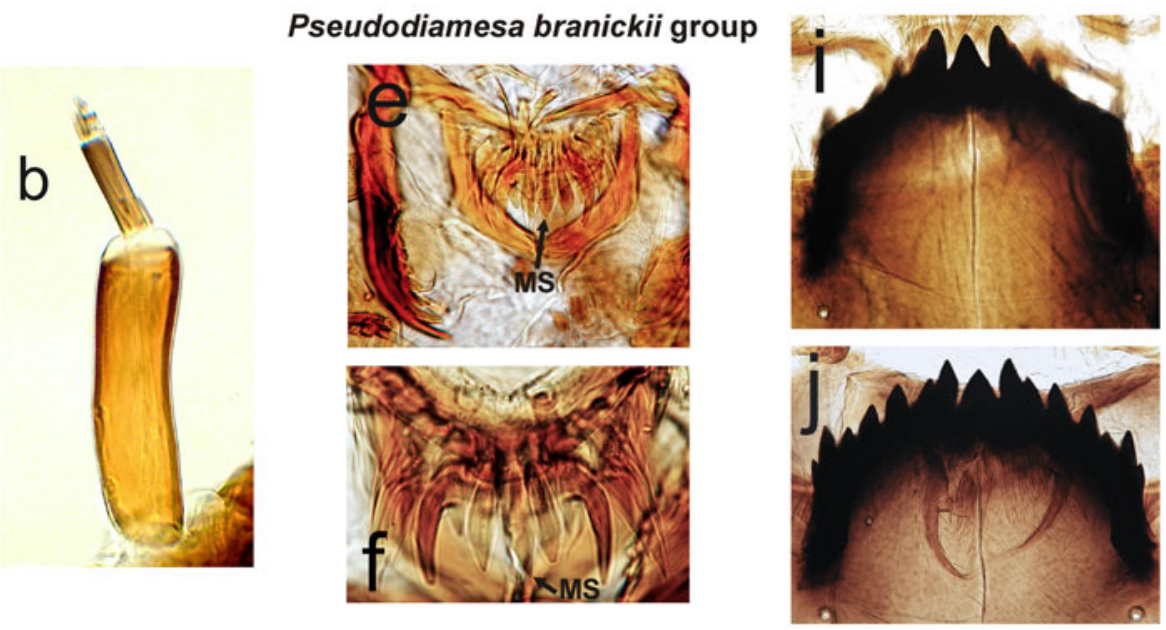

\section{Pseudodiamesa ind.}

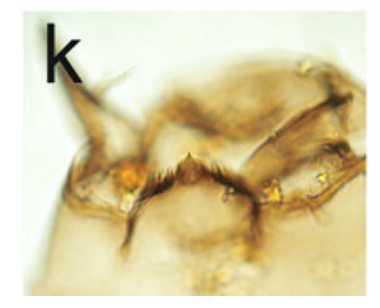

\section{Conclusions}

teeth are more visible in the unflattened mentum of the $P$. nivosa group than in that of the $P$. branickiigroup (Makarchenko 1985) (Fig. 1h, i). Finally, the 1 st and 2nd instars of both subgenera have an identical mentum, with a broad median tooth that is lighter than the lateral blackish teeth (Fig. 1k).

We concluded that the species-group morphotypes of Pseudodiamesa larvae can be differentiated within the subfossil material from surface and down-core samples using a combination of morphological 
characters, namely the mentum, pecten epipharyngis, and antennal ratio (Table 2). The Pseudodiamesa species groups from different zoogeographic regions demonstrate similar ecological preferences. Thus, more precise taxonomic identification and splitting of the genus into two intra-genus morphotypes could improve existing chironomid-temperature transfer functions and provide better palaeoclimate reconstructions and palaeolimnological interpretation of subfossil chironomid records.

Acknowledgments Data presented in this manuscript were produced, in part, during research funded by the European Commission (FP7-PEOPLE-2007-4-2-IIF-ENV, Marie Curie Fellow grant no. 219881 to B. Ilyashuk) and the Austrian Science Fund (FWF grant M964-N10 to E. Ilyashuk). We thank Karin Koinig and Roland Psenner (University of Innsbruck, Austria), and André F. Lotter (Utrecht University) for scientific and logistic support. We are grateful to Mark Brenner and two anonymous reviewers for their useful comments and suggestions on an earlier draft of the manuscript.

Open Access This article is distributed under the terms of the Creative Commons Attribution Noncommercial License which permits any noncommercial use, distribution, and reproduction in any medium, provided the original author(s) and source are credited.

\section{References}

Andreev AA, Tarasov PE, Schwamborn G, Ilyashuk BP, Ilyashuk EA, Bobrov AA, Klimanov VA, Rachold V, Hubberten H-W (2004) Holocene palaeoenvironmental records from Nikolay Lake, Lena River Delta, Arctic Russia. Palaeogeogr Palaeoclimatol Palaeoecol 209:197217

Barley EM, Walker IR, Kurek J, Cwynar LC, Mathewes RW, Gajewski K, Finney BP (2006) A northwest North American training set: distribution of freshwater midges in relation to air temperature and lake depth. J Paleolimnol 36:295-314

Bitušík P, Svitok M, Kološta P, Hubková M (2006) Classification of the Tatra Mountain lakes (Slovakia) using chironomids (Diptera, Chironomidae). Biologia 61(Suppl 18):191-201 Bratislava

Boggero A, Füreder L, Lencioni V, Simcic T, Thaler B, Ferrarese U, Lotter AF, Ettinger R (2006) Littoral chironomid communities of Alpine lakes in relation to environmental factors. Hydrobiologia 562:145-165

Braukmann U, Biss R (2004) Conceptual study—an improved method to assess acidification in German streams by using benthic macroinvertebrates. Limnologica 34:433-450

Bretschko G (1974) The chironomid fauna of a high-mountain lake (Vorderer Finstertaler See, Tyrol, Austria, 2237 m asl). Ent Tidskr Suppl 95:22-33
Brooks SJ, Langdon PG, Heiri O (2007) The identification and use of Palaearctic Chironomidae larvae in palaeoecology. QRA Technical Guide No. 10, Quaternary Research Association, London

Danks HV, Oliver DR (1972) Seasonal emergence of some high arctic Chironomidae (Diptera). Can Ent 104:661-686

Elgmork K, Sæther OA (1970) Distribution of invertebrates in a high mountain brook in the Colorado Rocky Mountains. Univ Colo Stud Ser Biol 31:1-55

Epler JH (2001) Identification manual for the larval Chironomidae (Diptera) of North and South Carolina. A guide to the taxonomy of the midges of the southeastern United States, including Florida. Special Publication SJ2001SP13. North Carolina Department of Environment and Natural Resources, Raleigh, NC, and St. Johns River Water Management District, Palatka, FL

Goetghebuer M (1933) Ceratopogonidae et Chironomidae nouveaux ou peu connus d'Europe (Troisième Note). Bull Ann Soc R d'Entomol Belg 73:209-221

Hågvar S, Østbye E (1973) Notes on some winter-active Chironomidae. Norsk Entomol Tisdsskr 20:253-257

Hayes BP, Murray DA (1987) Species composition and emergence of Chironomidae (Diptera) from three high arctic streams on Bathurst Island, Northwest Territories, Canada. Ent Scand Suppl 29:355-360

Hayford B (2005) New records of Chironomidae (Insecta: Diptera) from Mongolia with review of distribution and biogeography of Mongolian Chironomidae. J Kans Entomol Soc 78:192-200

Heiri O, Lotter AF (2008) Chironomidae (Diptera) in Alpine lakes: a study based on subfossil assemblages in lake surface sediments. Boletim do Museu Munic do Funchal Suppl 13:177-184

Ilyashuk EA, Heiri O, Koinig KA, Psenner R (2008) Holocene climatic changes in the Austrian Alps inferred from fossil chironomid assemblages. In: Geophysical research abstracts, vol 10, EGU2008-A-05428

Ilyashuk BP, Gobet E, Heiri O, Lotter AF, van Leeuwen JFN, van der Knaap WO, Ilyashuk EA, Oberli F, Ammann B (2009) Lateglacial environmental and climatic changes at the Maloja Pass, Central Swiss Alps, as recorded by chironomids and pollen. Quat Sci Rev 28:1340-1353

Janecek B (1998) Fauna Aquatica Austriaca, Taxonomie und Ökologie aquatischer wirbelloser Organismen, Teil V. Diptera: Chironomidae (Zuckmücken), Larvenstadien mitteleuropäischer Gattungen und österreichischer Arten, Bestimmung von 4. Universität für Bodenkultur, Abteilung Hydrobiology, Wien

Janecek B, Moritz C, Saxl R (2002) Diptera: Chironomidae: Diamesinae, Part III. In: Moog O (ed) Fauna Aquatica Austriaca, 2nd edn. Wasserwirtschaftskataster, Bundesministerium für Land- und Forstwirtschaft, Umwelt und Wasserwirtschaft, Wien

Kettani K, El Ouazzani T, Calle Martinez D (2001) Mise à jour de l'inventaire des Chironomidés (Diptera) connus du Maroc. Ann Limnol 37:323-333

Krno I, Šporka F, Galas J, Hamerlík L, Zatovičová Z, Bitušík P (2006) Littoral benthic macroinvertebrates of mountain lakes in the Tatra Mountains (Slovakia, Poland). Biologia 61(Suppl 18):147-166 Bratislava 
Kurek J, Cwynar LC, Vermaire JC (2009) A late Quaternary paleotemperature record from Hanging Lake, northern Yukon Territory, eastern Beringia. Quat Res 72:246-257

Langdon PG, Holmes N, Caseldine CJ (2008) Environmental controls on modern chironomid faunas from NW Iceland and implications for reconstructing climate change. J Paleolimnol 40:273-293

Larocque I, Hall RI, Grahn E (2001) Chironomids as indicators of climate change: a 100-lake training set from a subarctic region of northern Sweden (Lapland). J Paleolimnol 26:307-322

Lencioni V (2004) Survival strategies of freshwater insects in cold environments. J Limnol 63:45-55

Lencioni V, Rossaro B (2005) Microdistribution of chironomids (Diptera: Chironomidae) in Alpine streams: an autoecological perspective. Hydrobiologia 533:61-76

Lindegaard C (1992) Zoobenthos ecology of Thingvallavatn: vertical distribution, abundance, population dynamics and production. Oikos 64:257-304

Linevich AA (1989) Metamorphoz chironomidy Pseudodiamesa stackelbergi Goetgh. (Metamorphosis of chironomid Pseudodiamesa stackelbergi Goetgh). In: Linevich AA (ed) Fauna of Lake Baikal: worms, mollusks and arthropods. Nauka, Novosibirsk, pp 118-123

Lods-Crozet B, Castella E, Cambin D, Ilg C, Knispel S, Mayor-Siméant H (2001) Macroinvertebrate community structure in relation to environmental variables in a Swiss glacial stream. Freshw Biol 46:1641-1661

Mackay RJ (1969) Aquatic insect communities of a small stream on Mont St. Hilaire, Quebec. J Fish Res Bd Can 26:1157-1183

Makarchenko EA (1983) A new species of the genus Pseudodiamesa (Diptera, Chironomidae) from North Caucasus. Zoologicheskii Zhurnal 62:1909-1911

Makarchenko EA (1985) Chironomids of the Far East of USSR. The subfamilies Podonominae, Diamesinae, and Prodiamesinae (Diptera, Chironomidae). DVNC AN SSSR, Vladivostok

Makarchenko EA (1989) A review of the Diamesinae (Diptera, Chironomidae) from the USSR, with notes on systematics of Pseudodiamesa G. and Pagastia Ol. Acta Biologica Debrecen, Oecologica Hungarica 2:265-274

Makarchenko EA (1993) Diamesinae from Japan. Chironomus Newsl 5:13-14

Makarchenko EA (2006) Subfamily Diamesinae. In: Leley AS (ed) Key to the insects of the Russian Far East, vol 6, Diptera and Siphonaptera, part 4. Dal'nauka, Vladivostok, pp 253-276, 468-480, and 607-621

Makarchenko EA (2009) Pseudodiamesa nivosa (Goetghebuer, 1928 ) is not synonym of Pseudodiamesa arctica (Malloch, 1919) (Diptera: Chironomidae). XVII International Symposium on Chironomidae, July 5-10, 2009, Nankai University, Tianjin, China. Program and Abstracts, p 71

Makarchenko EA, Makarchenko MA (1999) Chironomidae. Non-biting midges. In: Tsalolikhin SJ (ed) Key to freshwater invertebrates of Russia and adjacent lands. Higher insects: Diptera, vol 4. Zoological Institute, St. Petersburg pp 210-295 and 670-857

Manca M, Ruggiu D, Panzani P, Asioli A, Mura G, Nocentini AM (1998) Report on a collection of aquatic organisms from high mountain lakes in the Khumbu Valley (Nepalese Himalayas). Mem Ist ital Idrobiol 57:77-98

Milner AM, Brittain JE, Castella E, Petts GE (2001) Trends of macro-invertebrate community structure in glacier-fed rivers in relation to environmental conditions: a synthesis. Freshw Biol 46:1833-1847

Nauwerck A (1981) Studies on the bottom fauna of the lake Latnjajaure (Swedish Lappland). Ber Nat Med Ver Innsbruck 68:79-98

Nolte U, Hoffmann T (1992) Life cycle of Pseudodiamesa branickii (Chironomidae) in a small upland stream. Aquat Ecol 26:309-314

Oliver DR (1959) Some Diamesini (Chironomidae) from the Nearctic and Palearctic. Ent Tidskr 80:48-64

Oliver DR (1964) A limnological investigation of a large arctic lake, Nettilling Lake, Baffin Island. Arctic 69-83

Oliver DR (1976) Chironomidae (Diptera) of Char Lake, Cornwallis Island, N.W.T., with descriptions of two new species. Can Ent 108:1053-1064

Oliver DR (1983) The larvae of Diamesinae (Diptera: Chironomidae) of the Holarctic region-keys and diagnoses. Ent Scand Suppl 19:115-138

Oliver DR (1989) The adult males of Diamesinae of the Holarctic region-keys and diagnoses. Ent Scand Suppl 34:129-154

Oliver DR, Dillon ME, Cranston PS (1990) A catalog of Nearctic Chironomidae. Research Branch, Agriculture Canada, Ottawa

Ørbæk JB, Tombre I, Kallenborn R (2004) Challenges in Arctic-Alpine environmental research. Arc Ant Alpine Res 36:281-283

Paasivirta L (2009) Chironomidae (Diptera: Nematocera) in the biogeographical provinces of Finland. http://www. ymparisto.fi

Pagast F (1947) Systematik und Verbreitung der um die Gattung Diamesa gruppierten Chironomiden. Arch Hydrobiol 41:435-596

Pankratova VY (1970) Larvae and pupae of non-biting midges of the subfamily Orthocladiinae (Diptera, Chironomidae Tendipedidae) of the USSR fauna. Opredeliteli Fauny SSSR 102:1-343

Rieradevall M, Prat N (1999) Chironomidae from high mountain lakes in Spain and Portugal. In: Hoffrichter O (ed) Late 20th century research on Chironomidae: an anthology from the 13th international symposium on Chironomidae. Shaker Verlag, Aachen, pp 605-613

Roback SS, Coffman WP (1987) Results of the Nepal Alpine Zone. Research project, Chironomidae (Diptera). Proc Acad Nat Sci Phila 139:87-158

Rossaro B, Lencioni V, Boggero A, Marziali L (2006) Chironomids from Southern Alpine running waters: ecology, biogeography. Hydrobiologia 562:231-246

Sæther OA (1970) Chironomids and other invertebrates from North Boudler Creek, Colorado. Univ Colo Stud Ser Biol 31:56-114

Sæther OA (1980) Glossary of chironomid morphology terminology (Diptera: Chironomidae). Ent Scand Suppl $14: 1-51$

Sæther OA, Spies M (2004) Fauna Europaea: Chironomidae. In: de Jong H (ed) Fauna Europaea: Diptera, Nematocera. Fauna Europaea version 1.1, http://www.faunaeur.org 
Schmid PE (1993) A Key to the larval Chironomidae and their instars from Austrian Danube Region streams and rivers. Part I, Diamesimae, Prodiamesinae and Orthocladiinae. Federal Institute for Water Quality of the Ministry of Agriculture and Forestry, Wien, Austria

Schnell ØA, Willassen E (1991) Fjærmyggarten Pseudodiamesa arctica (Malloch) i to høyfjellsreservoarer (The chironomid species Pseudodiamesa arctica (Malloch) in two high mountain reservoirs). Report No 76, Freshwater Ecology and Inland Fisheries Laboratory, Department of Zoology, University of Bergen, Bergen

Serra-Tosio B (1973) Ecologie et biogeography des Diamesini d'Europe (Diptera, Chironomidae). Trav Lab Hydrobiol Piscic Univ Grenoble 63:5-175

Serra-Tosio B (1976) Chironomides des Alpes: Le genre Pseudodiamesa (Diptera, Chironomidae). Trav Sci Parc Nat Vanoise 7:117-138
Siciński J (1988) New data on the rare species Pseudodiamesa nivosa (Goetghebuer) (Diptera, Chironomidae). Aquat Ins 10:73-76

Tanaka H, Sasa M (2001) Studies on the Chironomid species collected with light trap in Sunaba, Kurobe, during the winter Season from December to April, 2000. Trop Med 43:39-48

Tátosová J, Stuchlík E (2006) Seasonal dynamics of chironomids in the profundal zone of a mountain lake (Ľadové pleso, the Tatra Mountains, Slovakia). Biologia 61(Suppl 18):203-212 Bratislava

Walker IR, Cwynar LC (2006) Midges and palaeotemperature reconstruction - the North American experience. Quat Sci Rev 25:1911-1925 